\title{
Hydrology and beyond: the scientific work of August Colding revisited
}

\author{
Dan Rosbjerg \\ Department of Environmental Engineering, Technical University of Denmark, \\ Bygningstorvet, Building 115, 2800 Kongens Lyngby, Denmark
}

Correspondence: Dan Rosbjerg (daro@env.dtu.dk)

Received: 15 April 2020 - Discussion started: 30 April 2020

Revised: 1 August 2020 - Accepted: 10 August 2020 - Published: 22 September 2020

\begin{abstract}
August Colding was one of the three pioneers who in the mid-1800s almost simultaneously and independently formulated the first law of thermodynamics, the two others being Robert Mayer and James Joule. This first, significant achievement was followed by a sequence of other ground-breaking discoveries within a broad range of disciplines: magnetism, steam power, gas production, hydraulics, soil physics, hydrology, heating and ventilation, meteorology, and oceanography. Moreover, he made a significant contribution to the understanding of the spread of cholera. In hydrology, he used evaporation experiments to obtain water balances. Independently, he formulated Darcy's law and was the first to calculate the water table between drainpipes and the piezometric surface in confined aquifers. His main occupation, however, was chief engineer in Copenhagen, where he modernized the city by introducing groundwater-based water supply and building a waterworks delivering pressured, clean water into houses, a gasworks and gas-based street lighting, and a citywide sewage system. Colding has not been as recognized internationally as he might deserve, probably because most of his publications were written in Danish. Even in Denmark, he seems today almost forgotten. This paper highlights his most important scientific contributions, in particular his achievements in hydrology, hydraulics, meteorology, and oceanography.
\end{abstract}

\section{Introduction}

Ludvig August Colding (1815-1888) grew up on a farm close to Copenhagen but showed no interest in becoming a farmer. Instead, he was trained as a cabinet maker after ad- vice from Hans Christian Ørsted (the world-renowned physicist who discovered electro-magnetism), with whom his father was acquainted. This first training raised his interest for engineering, and, having passed the entrance examination, he started at the Polytechnic School, where Ørsted was director. During his studies, he assisted Ørsted by measuring the heat released from compression of water. He graduated in 1841, and after a couple of years with miscellaneous teaching activities, he was employed by the city of Copenhagen, first as road/bridge inspector and from 1845 as water inspector. In 1857 , he was promoted to become the first chief engineer in Copenhagen, a position he held until retirement in 1883. A photo of August Colding is seen in Fig. 1.

\section{The first law of thermodynamics}

During Colding's studies and his work as Ørsted's protégé, he became strongly interested in the nature of forces (motive force, heat, electricity, and chemical forces) and their possible disappearance. In 1843, he submitted a treatise concerning forces to the Royal Danish Academy of Sciences and Letters, but this was not printed before 1856 (Colding 1843/1856). He knew d'Alembert's principle for the equilibrium of lost forces. However, Colding's belief was that when and wherever a force seems to vanish in performing certain mechanical, chemical, or other work, the force then merely would undergo a transformation and reappear in a new form, but of the original amount (Caneva, 1998). Thus, Colding claimed the imperishability of forces. The term "force" has here been used in the same way as Colding did. In parallel, he also used the term "activity" of forces. In the first half of 


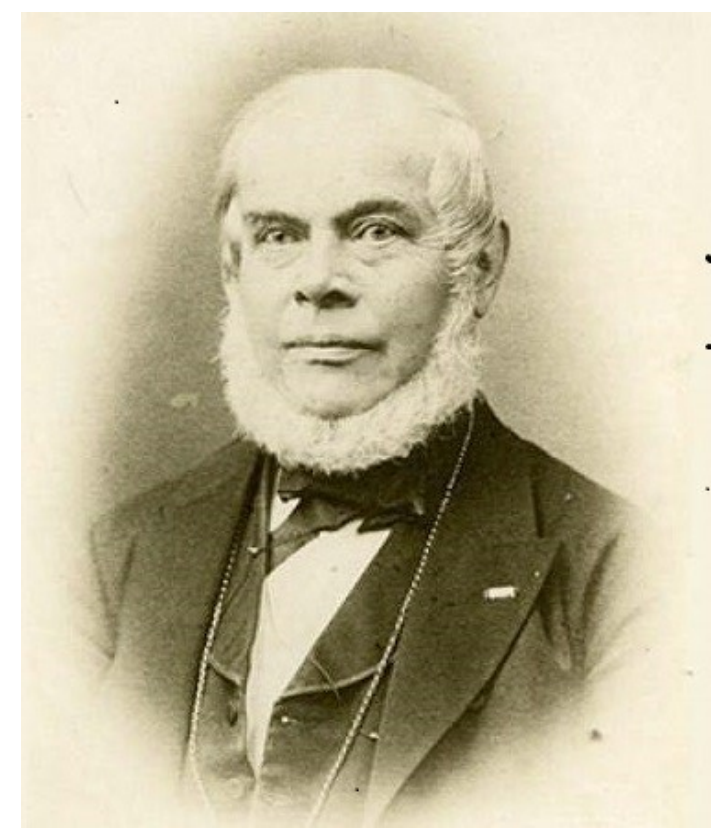

Figure 1. August Colding (Wikipedia).

the 1800 s, the term "energy" was not yet introduced as the work of a force.

To prove his statement, he performed a series of experiments, where a sled loaded with different cannonballs was dragged on rails of different metals. By measuring the heat expansion of the rails, he concluded that when we employ a motive force to overcome the resistance, which a body experiences in sliding over other bodies of a quite different nature, the heat evolved from the friction is strictly proportional to the work expended (Dahl, 1972). Later experiments using an improved experimental set-up (see Fig. 2) enabled him to estimate the mechanical equivalent of heat (Colding, 1851a). Unfortunately, Ørsted found it difficult to follow Colding's idea of imperishability of forces, which significantly delayed the publication of the treatise. Despite this delay, Colding claimed priority to the discovery, as did Mayer and Joule (Mayer, 1842; Joule, 1843; Kragh, 2009). The general perception of today is that all three should be considered equal.

In 1851, Colding demonstrated the generality of his theorem by also taking fluids and gases into account (Colding, $1851 \mathrm{~b}$ ), and he showed that the theorem could be used to improve the efficiency of steam engines (Colding, 1851c, 1853). He expanded the ideas further by a detailed investigation of the forces involved in magnetization of soft iron (Colding, 1851d). Much later the essence of his work on the first law of thermodynamics was translated into English and French (Colding, 1864a, b, 1871a).

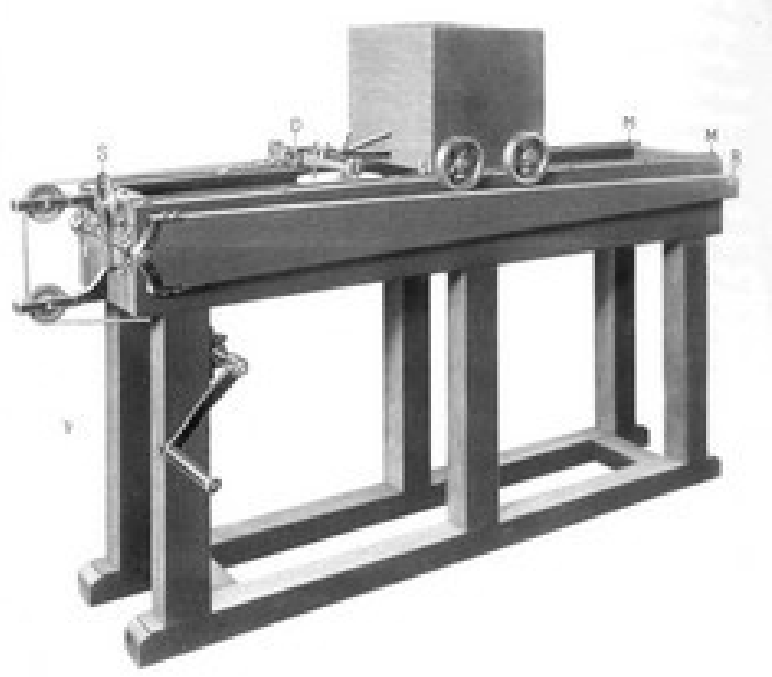

Figure 2. The experimental set-up for the first law of thermodynamics; measurements of heat expansion of rails of different metals caused by dragging a sled loaded with cannonballs along the rails (Danish Museum of Science and Technology).

\section{Responsible engineer for water supply, gas lighting, and sewerage in Copenhagen}

At that time, when Colding was employed by the city of Copenhagen, the water supply was insufficient and unhygienic. It was based partly on polluted wells in the city and partly on water from small surrounding lakes that was led into the city through leaky wooden pipes. Moreover, there was no sewerage, and the smell was terrible. In 1849, the city decided to remedy the situation and launched international competitions on, respectively, water supply, gas lighting, and sewerage projects. Colding won the water supply competition with an innovative project suggesting that the surface water from a lake west of Copenhagen should be supplemented with groundwater from surrounding artesian wells. Sand filtering was introduced and a waterworks powered by steam engines built along with a clean water consumptionequalizing reservoir close to the city.

Before the three projects were finally decided, a cholera epidemic hit Copenhagen in 1853. Almost 5000 people died. Together with a younger colleague, Julius Thomsen (later a famous chemist), Colding immediately investigated the causes of the spread of the disease, and they found that the spread was strongly correlated with the soil water quality (pollution) and the population density in different city sections. The ground-breaking work was published already the same year (Colding and Thomsen, 1853). A year later, John Snow in London gave the final proof of cholera being water borne.

Colding was appointed managing engineer for all the above three projects. While the water supply and the gas lighting projects were smoothly approved and initiated, the 
government heavily delayed the sewerage project despite the tragic cholera epidemic by requiring extensive modifications. Colding had to revise the winning far-sighted project that was based on separation of rainwater and sewage water, a project that was 100 years ahead of its time. Instead, a combined sewer was decided on without allowance for water closets. This was, however, still a significant improvement. The new water supply and the gas lighting projects were inaugurated in 1859 , while the sewerage project was accomplished during the 1860 s.

\section{The laws for water flow in filled and partly filled conduits}

At the time when Colding was to design the sewerage system in Copenhagen, there was no established practise for dimensioning of conduits, form of the conduits (prismatic, circular, or oval-shaped), and their material. In particular, the capacity of a given pipe (the flow rate) was under discussion. A sewerage commission in London had performed some fullscale experiments, where they found that Eytelwein's formula was not applicable (a pre-runner of the formula today known as the Darcy-Weisbach equation for steady, uniform flow in pipes and canals). Colding was not convinced and performed a thorough theoretical analysis, coming to the opposite conclusion, i.e. that Eytelwein's formula (Eytelwein, 1842) in fact was valid and that the seeming divergence was because the pipe system had to be filled up before the formula was applicable.

In Colding (1875b) Eytelwein's formula is presented as

$\gamma H s=\frac{\alpha}{2} \rho c L v^{2}$,

where $\gamma$ is the specific weight, $H$ is the head loss, $s$ is the cross-sectional area of the pipe, $\alpha$ is a friction factor, $\rho$ is the density, $c$ is the wetted perimeter, $L$ is the length of the pipe, and $v$ is the cross-sectional average velocity. Assuming that the pipe is circular and filled, we get $s=\pi D^{2} / 4=\pi D R$, where the hydraulic radius $R=D / 4$ is introduced, and by setting $H / L=S_{\mathrm{f}}$ (the friction slope), we find by solving for $v$ that

$v=\sqrt{\frac{2 g}{\alpha} R S_{\mathrm{f}}}$,

which is the Darcy-Weisbach equation, except that $\alpha=f / 4$, where $f$ is the more commonly used friction factor.

To obtain a further solid foundation for the project, it was decided that Colding should perform large-scale experiments in Copenhagen with salt-glazed pipes. Two series of circular pipe experiments were carried out with dimensions of, respectively, approximately $10 \mathrm{~cm}$ and $30 \mathrm{~cm}$; see Fig. 3. The length of the pipes was 297 feet (almost $100 \mathrm{~m}$ ). The experiments were carried out with both filled and partly filled pipes. The hydraulic head could be monitored at 12 stations along the pipe, and it was made possible to add water to a partly filled pipe at intakes along the conduits. Colding found that the added water only had a local effect, implying the Eytelwein formula to be applicable in general. The experimental measurements were supplemented by thorough, theoretical considerations including calculation of the friction factor (Colding, 1857).

\section{Evaporation, percolation, and water balance}

To evaluate the available amount of water for the new water supply to Copenhagen, Colding initiated precipitation measurement near four lakes around Copenhagen during a period of 12 years (1848-1859). He measured outflow from the lakes and invented a system for reliable measurements of the evaporation from a lake (Colding, 1860). A sheet metal box was placed on a float in the lake, partly submersed such that the surface of the water in the box was approximately equal to the surface of the lake. In that way, the error due to different temperature in the lake and the box was minimized. Moreover, the box was shielded to avoid errors due to wave splash. To assess evaporation from surroundings of the lake, he supplemented the experiments by monitoring evaporation from wetted short and long grass, in which case he used weighting of the box, as the water level in the box was difficult to determine. By measuring the precipitation on a lake and the amount of evaporation and by monitoring the lake outflow, he was able to obtain rather precise estimates of the lake inflow. Moreover, in addition to monitoring of precipitation and evaporation, Colding established two sets of tile drain experiments, one in sandy soil and one in clayey soil. By measuring the drain water flow, he could assess the infiltration and its dependence on soil type, precipitation, and seasonality and establish local water balances, separating the precipitation into surface runoff, evapotranspiration, and percolation, assuming that the amount of drain water under natural conditions would percolate to the aquifer. Colding maintained a lifelong interest in evaporation, and it can be seen in his personal papers that he was working on a formula for evaporation from a land surface.

\section{The free surface forms in conduits with constant flow}

During the experiments with flow in conduits, Colding became interested in investigating the possible forms of the water table in steady, non-uniform flow in prismatic and cylindrical channels. The starting point again was Eytelwein's formula for steady, uniform channel flow. He transformed the coordinates to be parallel and perpendicular to the direction of the conduit and initiated a complete mathematicalphysical analysis. Depending on the slope of the conduit and the inflow and outflow conditions, he could calculate the surface forms. For rectangular conduits, he identified and de- 


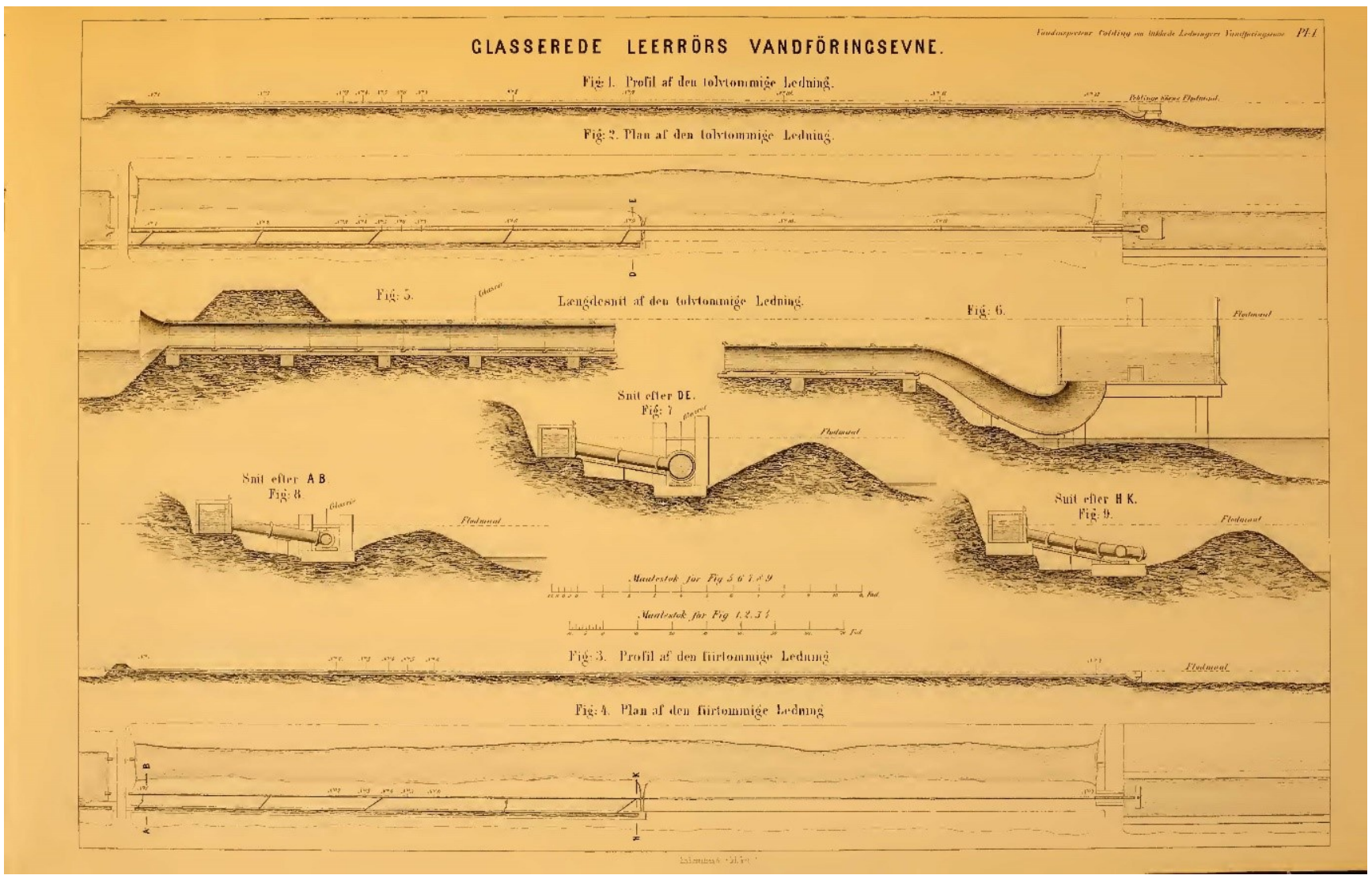

Figure 3. Large-scale experiments (100 m length) with filled and partly filled conduits (respectively, approximately $10 \mathrm{~cm}$ and $30 \mathrm{~cm}$ in diameter), including inlets along the pipe (Colding, 1857).

scribed mathematically six different forms. In addition, the surface form due to damming of water was considered.

Cylindrical conduits were analysed to the same degree of completeness. This resulted in identification of 14 different water surface forms. This included also minor differences in the forms. Today, only principally different forms are treated in textbooks. Two examples of the surface forms in a circular conduit, a concave and a convex, are shown in Fig. 4. It is likely that Colding was the first to present such a complete theory. The treatise (Colding, 1867), however, was written in Danish and never cited in the international literature.

\section{Outflow of heat from pipes carrying hot water}

The reason for Colding to engage in this problem was his disagreement with Dulong and Petit, who, based on a series of experiments, in 1818 had published a treatise casting doubt on Newton's theory for heat transport. Colding's starting point was the heat equation by Poisson, which he, by considering heat loss from a pipe with flowing water, integrated and found in complete agreement with Newton's theory. He also carried out several series of experiments measuring the changing temperatures throughout a pipe with flowing water.
The experiments were outdoor and large scale (pipe diameter $2.5 \mathrm{~cm}$ and pipe length $63.5 \mathrm{~m}$ ) (see Fig. 5) and performed in wintertime. Having found complete agreement with his theoretical calculations, he continued with heat emission from the pipe after cessation of the flow. In this case, the agreement with Newton was not immediately obtained, as the results rather pointed to the correctness of Dulong and Petit. However, by taking into account the difference in heat transport between flowing and stagnant water in the pipe he could, using advanced mathematics, explain the apparent deviation (Colding, 1868).

\section{On the laws of currents in ordinary conduits and in the sea}

So far, Colding had successfully used Eytelwein's formula for the mean flow in prismatic and cylindrical conduits with constant slope. He was, however, also interested in the velocity distribution in a cross section of the conduit. To that end, he used comprehensive measurements carried out by, respectively, Boileau (1854), Darcy (1858), and Bazin (1865) to develop a complete theory based on action and reaction throughout the cross section originating from the wall fric- 

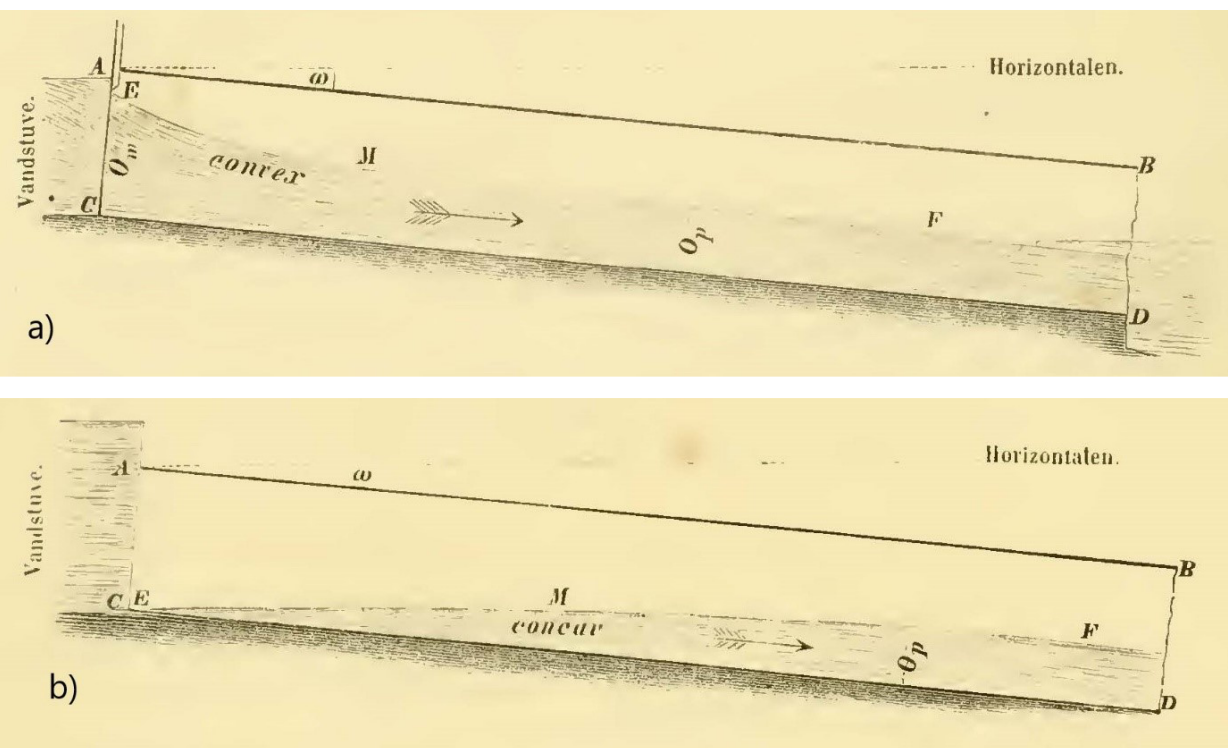

Figure 4. Examples of surface forms in steady, non-uniform flow in circular conduits (theoretical results); (a) convex surface; (b) concave surface (Colding, 1867).

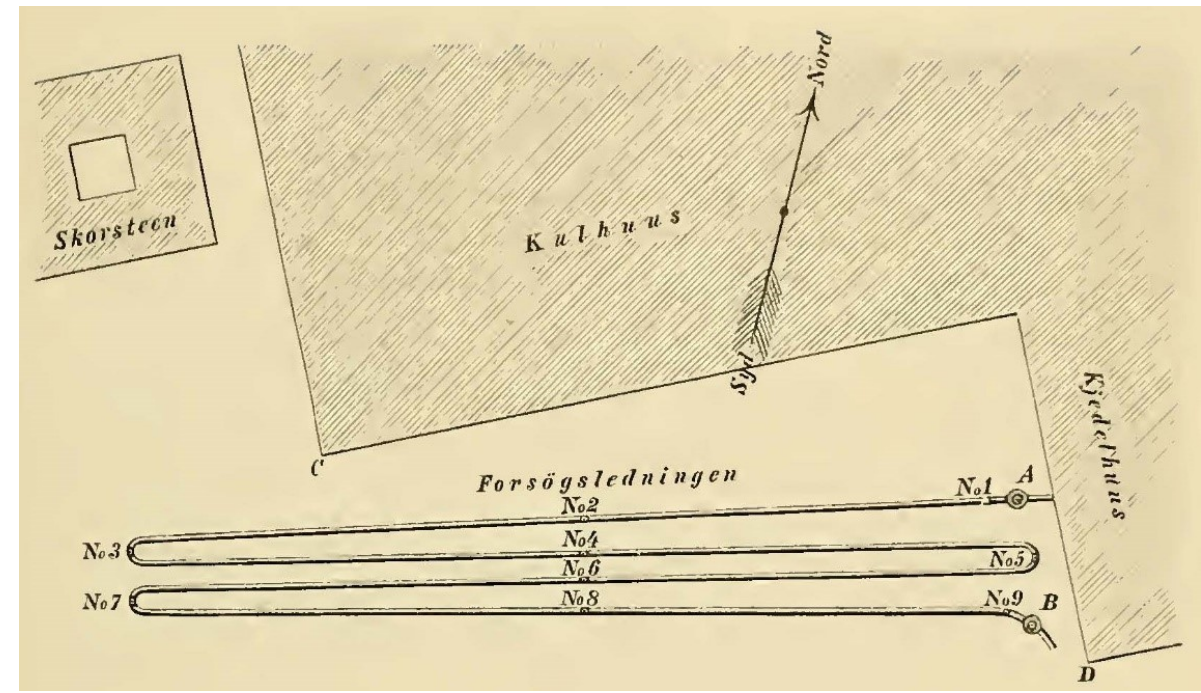

Figure 5. The large-scale experimental set-up (pipe diameter $2.5 \mathrm{~cm}$; pipe length $64.5 \mathrm{~m}$ ) for measuring the heat loss from a pipe carrying hot water (Colding, 1868).

tion. Bolieau had found that the maximum velocity in an open prismatic conduit might occur slightly below the surface, which was in accordance with some experiments. Colding showed that this was theoretically impossible without disturbances of the flow and found that even minor wind effects could be the reason. Using advanced mathematics, Colding calculated the cross-sectional velocity distributions, which were convincingly verified by the French experiments (Colding, 1870). A couple of examples are shown in Fig. 6. The developed theory for steady, uniform flow was finally shown also to be valid for steady, non-uniform flow.
In order to extend the theory to apply to currents in the sea with no walls to confine the current, he collected all available information about the Gulf Stream (i.a. U.S. Coast Survey, 1851, 1855, 1860; Irminger, 1853, 1861; Maury, 1855; Forchhammer, 1859; Kohl, 1868). He did not agree with Maury that the Gulf Stream was caused by a larger salinity in the Caribbean Sea than at higher northern latitudes. Colding showed that the primary cause of the onset of the stream is the high water level in the Caribbean due to the effect of the trade winds. He put forward a complete physical/mathematical theory for the progress of the 


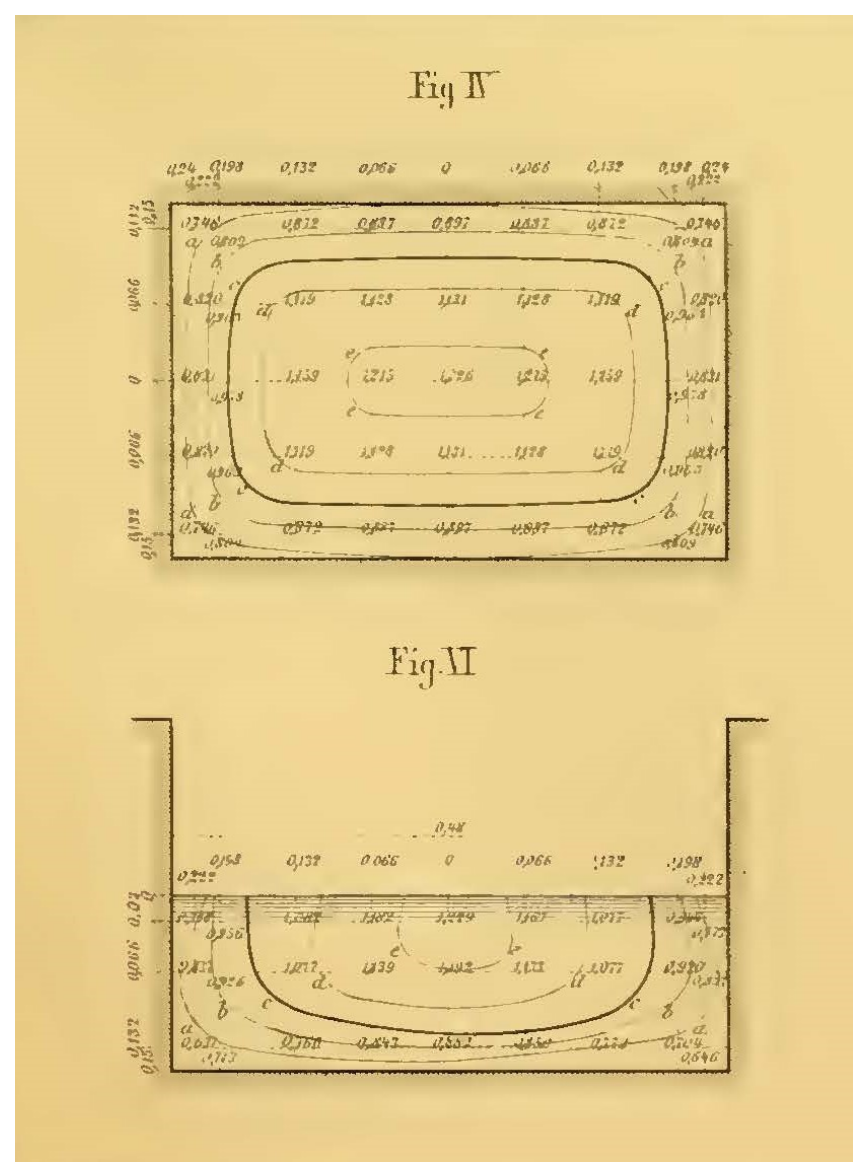

Figure 6. The cross-sectional velocity distribution in closed and open conduits (Colding, 1870).

stream, including the total onset volume and the volumes of the different branches the stream splits into when approaching the European continent (Colding, 1870). He argued that the progress of the stream is dominated by the effect of the Earth's rotation but also affected by many other elements like the return of the polar stream, the net evaporation from the sea, and changing temperatures. Colding discussed in detail all these factors. An overview of the Gulf Stream from Colding's treatise is shown in Fig. 7. A strongly abbreviated version of the treatise was later published in Nature (Colding, $1871 b, c, d)$.

\section{On the flow of air in the atmosphere}

Colding had a strong interest in meteorological phenomena and applied the knowledge obtained from the free currents in the sea to describe flow of air in the atmosphere. First, he showed that the mathematical description of a rotating water whirl could be used to describe the movement of air in a cyclone; see Fig. 8. The result was verified using observations of wind speed and air pressure during the Antigua cyclone of 2 August 1837 (Colding, 1871e). He then described the primary global weather phenomena using the experience from the analysis of the Gulf Stream. Unfortunately, Colding did not entirely correctly include the influence of the rotation of the Earth, the Coriolis force (Coriolis, 1835) (not until the 20th century did the Coriolis force begin to be applied, first by meteorologists). This was particularly critical for the large-scale wind systems but not for the cyclone theory. When he later realized the mistake, he initiated a revision of the free flow theory but died before it was completed.

Colding used the cyclone theory once more to assess the wind speeds around St. Thomas during the cyclone that passed the island on 21 August 1871. Air pressure observations from surrounding ships were included, which made Colding able to obtain a detailed description of the track of the cyclone and the wind speeds during the passage. The island was not damaged as much as during the 1837 cyclone, which corresponded well to Colding's assessment of the wind speeds and the storm track (Colding, 1871f). The airflow theory was later published in German (Colding, 1875a).

\section{On the laws for movement of water in soil}

After establishment of a number of artesian groundwater wells with the first one drilled in 1851, Colding closely followed the yield of the wells during the following years. He observed that the yield varied seasonally, with a maximum in wintertime and between wet and dry years. By analysing the yield as a function of the piezometric head, he found the general law for movement of water in soil, i.e. the proportionality between the head gradient and the velocity known as the Darcy equation.

To verify this finding, he established a series of experiments using a measurement box of length $350 \mathrm{~cm}$, depth $42 \mathrm{~cm}$, and width $58 \mathrm{~cm}$. The inner cross section was $2165 \mathrm{~cm}^{2}$. To distribute the inflow, the box was divided into a small inlet section of length $30 \mathrm{~cm}$, leaving the length of the experimental section to $320 \mathrm{~cm}$. In both ends of this section, there was a layer of pebbles to ensure uniform inflow and outflow, implying that the length of soil to be investigated was $260 \mathrm{~cm}$. By varying the soil type and the slope of the experimental box, Colding was able to verify the proportionality between the head gradient and the velocity and its dependence on soil type. Colding knew and used the pipe experiments by Darcy but was unaware of his groundwater work (Darcy, 1856). Thus, he independently came to the same conclusion a few years later (Colding, 1972).

For a confined aquifer draining to open water, he found approximately a parabolic piezometric surface; see Fig. 9. After some calculations he arrived with an equation “... der, som man seer, er Ligningen for en Parabel, hvis Axe er vertikal og hvis Toppunkt ligger paa det Sted i Terrainet, hvor Hastigheden $v=0$, og hvor altsaa Vandskjellet for de underjordiske Strømme findes, hvorfra Vandet bevæger sig til begge Sider; ...” (“... which, as can be seen, is the equa- 


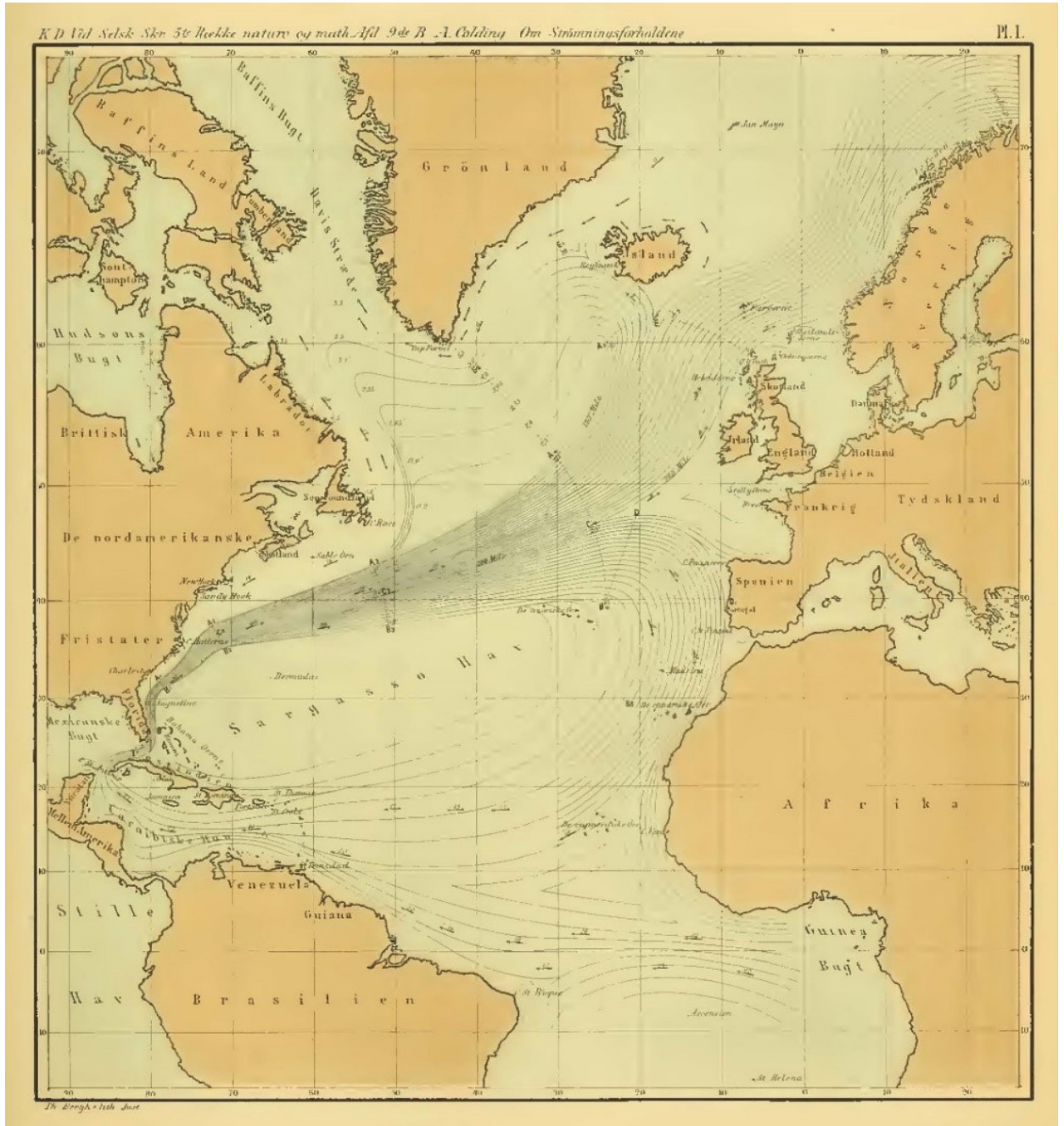

Figure 7. The Gulf Stream (Colding, 1870).

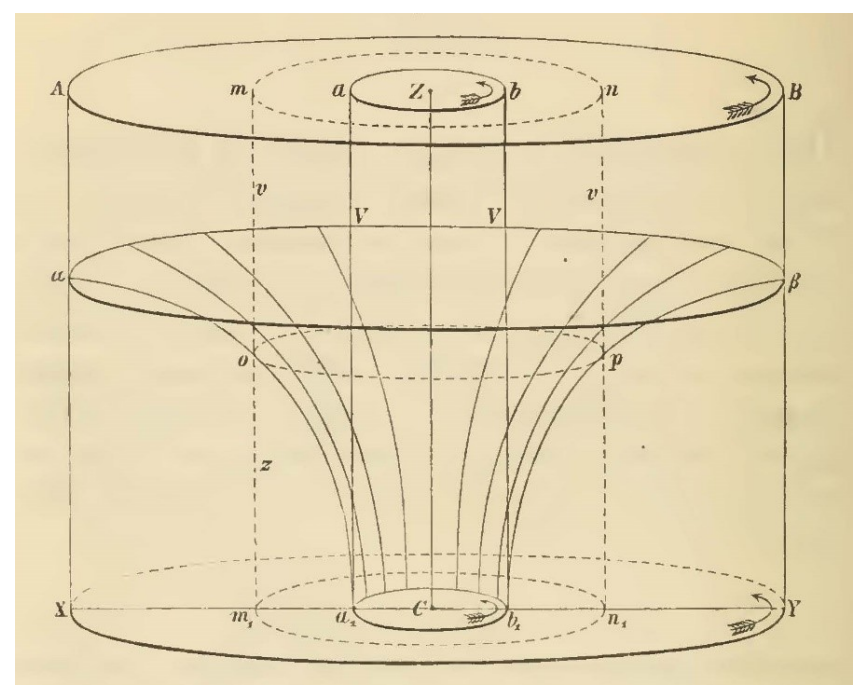

Figure 8. The water whirl used as an analogue to a cyclone (Colding, 1871e). tion for a parabola with vertical axis located where the velocity $v=0$, and where the water divide for the subterranean streams can be found, and from where the water moves in both directions; ...").

The drain experiments Colding used to assess percolation was subject to a more profound analytical analysis, where he could show that the water table between the pipes was elliptic; see Fig. 10. "Af formel (14) fremgaar, at Grundvandsspeilet har Form som af en Ellipse, hvis ene Axe $(\lambda)$ er horizontal, beliggende I Strømmens Retning, og hvis anden Axe $(U)$ staar lodret på den første." ("Formula (14) shows that the groundwater table has form of an ellipse, whose first axis $(\lambda)$ is horizontal, located in the direction for the stream, and second axis perpendicular to the first.") The theoretical findings for drainage through drainpipes were accompanied by general recommendations for establishment of drainpipe systems in agricultural fields. As noticed by Brutsaert (2005), Colding was the first to determine the elliptic water table between parallel drainpipes; see Fig. 10. How- 


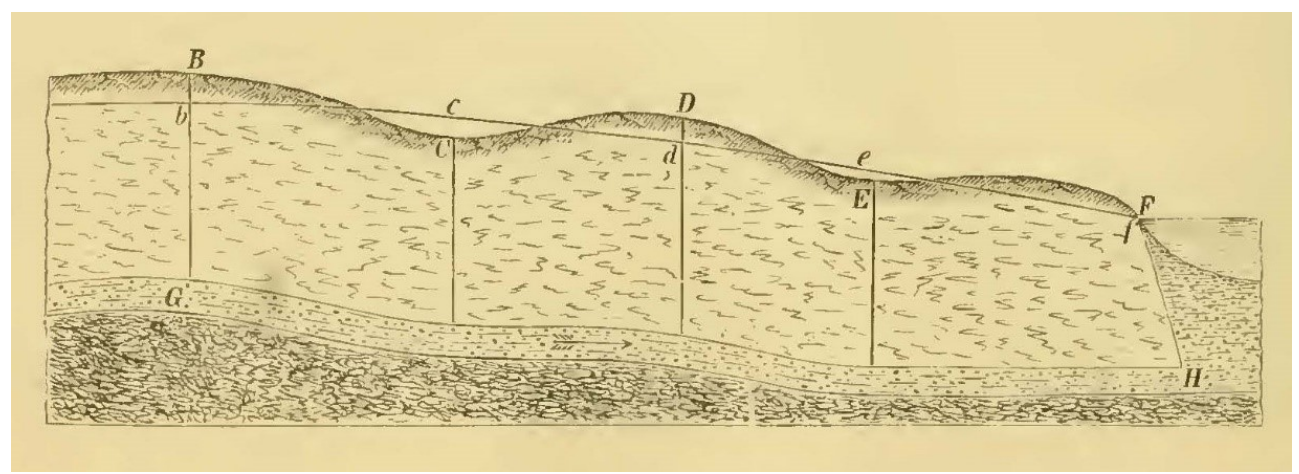

Figure 9. Approximate parabolic piezometric surface for a confined aquifer draining to open water. The soil surface is marked B-C-D-E-F, the piezometric surface b-c-d-e-f, and the confined aquifer G-H (Colding, 1872).

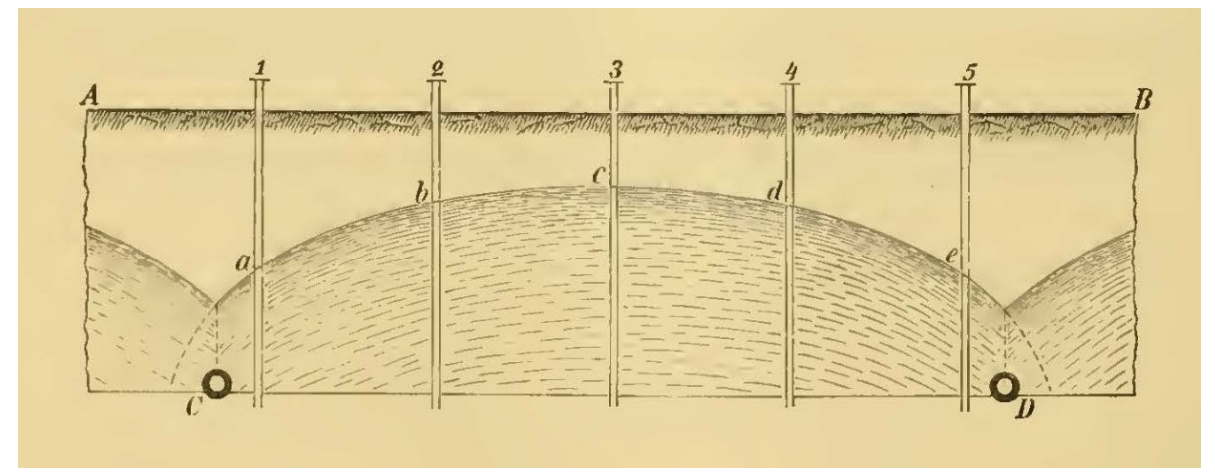

Figure 10. Elliptic water table (a-b-c-d-e) between drainpipes (Colding, 1872).

ever, Brutseart did not provide a reference to Colding's work. Linking Colding's name to the elliptic water table ("Colding's drain model"?) might allow him a deserved recognition in hydrological science.

\section{On the wind-induced currents in the sea}

The background for the last ground-breaking work of Colding was a partial flooding of the southern Danish islands Lolland and Falster during a severe storm on 12-14 November 1872 , where 80 people died and about 500 ships were stranded. Colding wanted to describe the cause of the flooding and hypothesized that the wind forces' impact on the sea could fully explain the incident, as the tidal influence in the Baltic Sea is minimal. As a first necessary step, he developed a complete theory for wind set-up in a wide channel including expressions for the set-up depending on the wind speed relative to the original flow velocity (Colding, 1876).

Immediately after the storm, he had initiated a wide data collection, both nationally and internationally, to get information on water levels, air pressure, and wind speed and direction. On this basis, he developed synoptic weather maps including water levels for every $6 \mathrm{~h}$ during the storm. An example is shown in Fig. 11. For a number of sections in the
Baltic Sea he subsequently calculated the wind set-up according to his previously developed theory. This resulted in a remarkable match proving that in fact it was the wind that caused the flooding. Using the synoptic maps, he was able to explain the storm development in detail. Finally, he added calculations of the water flow through the Danish straits during the storm (Colding, 1881). Subsequent design of dikes to prevent future flooding was based on Colding's theory.

\section{Final remarks}

Every second year between 1865 and 1883 Colding taught a course at the Polytechnic School on the basic laws for discharge of sewage, water and gas supply, and heating and ventilation. His handwritten lecture notes (Colding, 1875b) are still kept; see Fig. 12. In 1869, he was appointed as professor at the school. Two years earlier he had been made a knight of the Order of Dannebrog, and in 1871 he received an honorary doctoral degree at the University of Edinburgh simultaneously with Joule. Since 1856, he had been a member of the Royal Danish Society of Sciences and Letters, and in 1875, he also joined the Royal Swedish Academy of Science. It is evident that Colding nationally became highly valued in his lifetime both for his scientific achievements and for his en- 


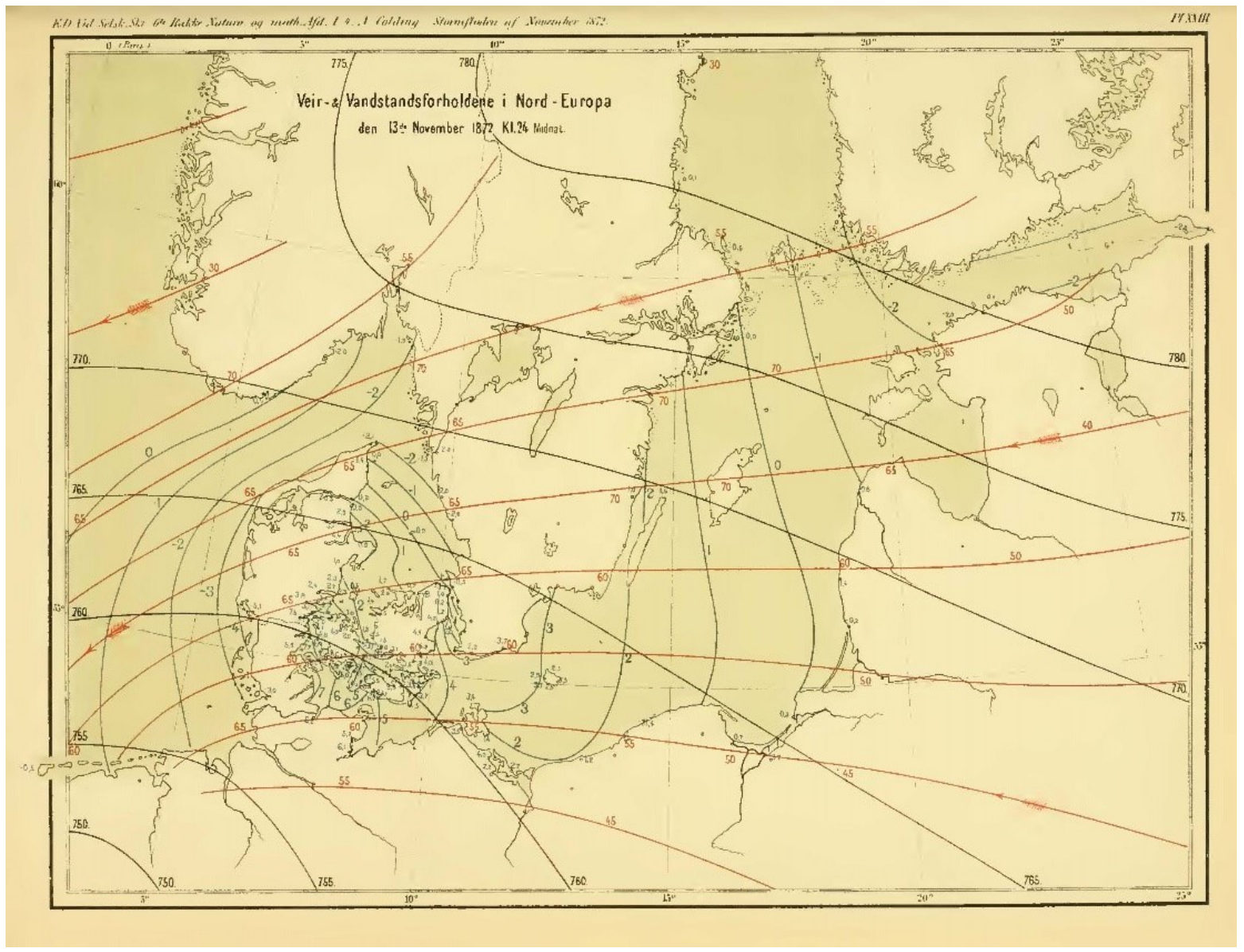

Figure 11. One of several synoptic weather maps from the 1872 storm in the Baltic Sea (Colding, 1881).

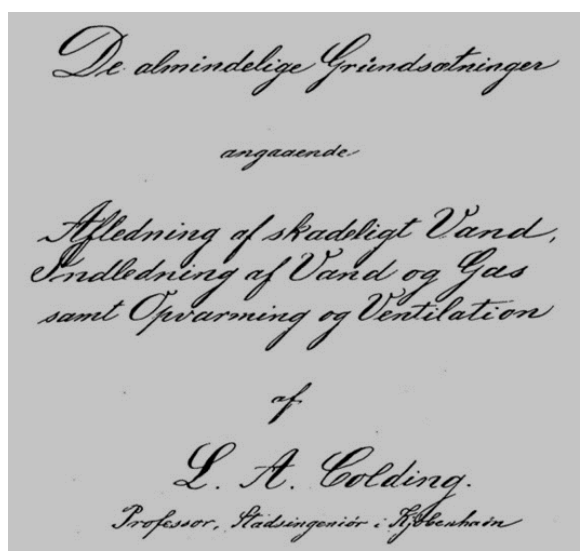

Figure 12. Front page of Colding's handwritten 310-page long lecture notes (Colding, 1875b).

deavours for the city of Copenhagen. However, even though he was a scientific frontrunner in many respects, he seems nowadays almost forgotten. Maybe the above overview of his extremely diversified and original research can lead to a renewed interest and appreciation.
Data availability. All available data are provided in the references.

Competing interests. The author declares that there is no conflict of interest.

Special issue statement. This article is part of the special issue "History of hydrology" (HESS/HGSS inter-journal SI). It is not associated with a conference.

Acknowledgements. The author is grateful for the comments provided by Allan Rodhe and one anonymous referee and the editor Keith Beven.

Review statement. This paper was edited by Keith Beven and reviewed by Allan Rodhe and one anonymous referee. 


\section{References}

Bazin, H.: Recherches hydrauliques sur l'écoulement de l'eau dans les canaux découvertes et sur la propagation des endes, Dunod, Paris, France, 1865.

Boileau, P. P.: Traité de la mesure des eaux courantes, MalletBachelier, Paris, France, 1854.

Brutsaert, W.: Hydrology - An introduction, Cambridge University Press, Cambridge, UK, 2005.

Caneva, K.: Colding, Ørsted, and the meanings of force, Hist. Stud. Phys. Biol., 28, 1-138, 1998.

Colding, L. A.: Nogle Sætninger om Kræfterne (Treatise concerning forces), printed 1856 in Videnskabernes Selskabs (Note: "Videnskabernes Selskab" refers to "The Royal Danish Society of Sciences and Letters") Forhandlinger, 3-20, 1843/1856.

Colding, L. A.: Undersögelse om de almindelige Naturkræfter og deres gjensidige Afhængighed (Investigation of the common nature forces and their mutual dependency), Videnskabernes Selskabs Skrifter, 5, 121-146, 1851a.

Colding, L. A.: Om de almindelige Naturkræfter og deres gjensidige Afhængighed (On the common nature forces and their mutual dependency), Videnskabernes Selskabs Skrifter, 5, 167-188, $1851 b$.

Colding, A.: An examination of steam engines and the the power of steam in connection with an improvement of steam engines, Louis Klein, Copenhagen, Denmark, 15 pp., 1851c.

Colding, L. A.: Om Magnetens Indvirkning på blödt Jern (On the effect of magnets on soft iron), Videnskabernes Selskabs Skrifter, $5,147-166,1851 \mathrm{~d}$.

Colding, A.: Undersögelse over Vanddampene og deres bevægende Kraft i Dampmaskinen (Investigation of steam and its moving force in steam engines), Videnskabernes Selskabs Skrifter, 5, 136,1853 .

Colding, A.: Om Lovene for Vandets Bevægelse i lukkede Ledninger, med speciel Anvendelse paa de saltglasserede Leerrörs Vandföringsevne (On the laws for water movement in closed conduits with special application on salt-glazed clay pipes), Videnskabernes Selskabs Skrifter, 5, 305-348, 1857.

Colding, A.: Resultaternes af nogle Iagttagelser om forskjellige Fugtighedsforhold i Omegnen af Kjøbenhavn (The results of some observations of different moisture conditions in the surroundings of Copenhagen), Tidsskrift for Landoekonomie, 3, 309-330, 1860 .

Colding, A.: On the history of the principle of the conservation of energy, Philos. Mag., 4, 56-64, 1864a.

Colding, A.: Sur l'histoire du principe de la conservation de l'énergie, Ann. Chim. Phys., 4, 466-477, 1864b.

Colding, A.: De frie Vandspeilsformer i Ledninger med constant Vandføring (The free surface forms in conduits with constant flow), Videnskabernes Selskabs Skrifter, 5, 1-96, 1867.

Colding, A.: Om Udstrømning af Varme fra Ledninger for varmt Vand (On outflow of heat from pipes carrying hot water), Videnskabernes Selskabs Skrifter, 5, 75-138, 1868.

Colding, A.: Om Strømningsforholdene i almindelige Ledninger og i Havet (On the flow patterns in ordinary conduits and in the sea), Videnskabernes Selskabs Skrifter, 5, 81-232, 1870.

Colding, A.: On the universal powers of nature and their mutual dependence, Philos. Mag., 4, 1-20, 1871a.

Colding, A.: On the laws of currents in ordinary conduits and in the sea, Part I, Nature, 5, 71-73, 1871 b.
Colding, A.: On the laws of currents in ordinary conduits and in the sea, Part II, Nature, 5, 90-92, 1871c.

Colding, A.: On the laws of currents in ordinary conduits and in the sea, Part III, Nature, 5, 112-114,1871d.

Colding, A.: Nogle Bemærkninger om Luftens Strømningsforhold (Some remarks on the flow of air), Videnskabernes Selskabs Forhandlinger, 89-108, 1871e.

Colding, A.: Om Hvirvelstormen på St. Thomas den 24. August 1871 (On the cyclone that hit St. Thomas 24 August 1871), Videnskabernes Selskabs Forhandlinger, 109-126, 1871 f.

Colding, A.: Om lovene for Vandets Bevægelse i Jorden (On the laws for movement of water in soil), Videnskabernes Selskabs Skrifter, 5, 563-622, 1872.

Colding, A.: Einige Bemerkungen zu den Strömungsverhältnissen der Luft, Zeitschrift der Österreichischen Gesellschaft für Meteorologie, 10, 133-142, 1875a.

Colding, L. A.: De almindelige Grundsætninger angaaende Afledning af skadeligt Vand, Indledning af Vand og Gas samt Opvarmning og Ventilation (The basic laws for discharge of sewage, water and gas supply, and heating and ventilation), Forelæsningsrække ved Polyteknisk Læreanstalt, Copenhagen, Denmark, 310 pp., $1875 b$.

Colding, A.: Fremstilling af Resultaterne af nogle Undersøgelser over de ved Vindens Kraft fremkaldte Strømninger i Havet (The resulting sea water flow caused by wind friction), Videnskabernes Selskabs Skrifter, 5, 246-274, 1876.

Colding, A.: Nogle Undersøgelser over Stormen over Nord- og Mellemeuropa af 12te-14de November 1872 og over den dermed fremkaldte Vandflod i Østersøen (The 1972 storm in the Baltic Sea and resulting flooding of the southern Danish islands), Videnskabernes Selskabs Skrifter, 6, 243-304, 1881.

Colding, A. and Thomsen, J.: Om de sandsynlige Årsager til Choleraens ulige Styrke i de forskellige Dele af Kjöbenhavn og om Midlerne til i Fremtiden at formindske Sygdommens Styrke (The probable causes of the unequal intensity of cholera in the different parts of Copenhagen and the means for decreasing the intensity of the plague for the future), Reitzel, Copenhagen, Denmark, 112 pp., 1853.

Coriolis, G.-G.: Mémoire sur les équations du mouvement relatif des systemes de corps, Journal de l'école Polytechnique, 15, 142-154, 1835.

Dahl, P. F.: Ludvig Colding and the Conservation of Energy Principle, The Sources of Science No. 104, Johnson Reprint Cooperation, New York, USA, 1972.

Darcy, H.: Les fontaines publiques de la ville de Dijon, Dalmont, Paris, France, 1856.

Darcy, H.: Recherches expérimentelles au movement de l'eau dans les tuyaux, Mallet-Bachelier, Paris, France, 1857.

Eytelwein, J. A.: Handbuch der Mechanik Fester Körper und der Hydraulik, 3rd edn., Koechly, Leipzig, Germany, 1842.

Forchhammer, J. G.: Om Søvandets Bestanddele og deres Fordeling i Havet (On the constitution of sea water at different depths and in different latitudes), Reitzel, Copenhagen, Denmark, 1859.

Irminger, C.: Om Havets Strømninger m. m. (On the currents in the sea), Nyt Archiv for Søvæsenet, Copenhagen, Denmark, 1853.

Irminger, C.: Strømninger og Isdrift ved Island (Currents and ice drift around Iceland), Tidsskrift for Søvæsen, Copenhagen, Denmark, 1861. 
Joule, J. P.: On the calorific effects of magneto-electricity, and on the mechanical value of heat, Philis. Mag., 3, 263-276, 347-355, 435-443, 1843.

Kohl, J. G.: Geschichte des Golfstroms, Müller, Bremen, Germany, 1868.

Kragh, H.: Conservation and controversy: Ludvig Colding and the imperishability of "forces", Research Publications on Science Studies, 4, Centre for Science Studies, University of Aarhus, Aarhus, Denmark, 27 pp., 2009.

Maury, M. F.: The Physical Geography of the Sea, 3rd edn., New York, USA, 1855.
Mayer, J. R.: Bemerkungen Uber die Kräfte der Unbelebten Natur, Annalen der Chemie und Pharmacie, 42, 233-240, 1842.

U.S. Coast Survey: Report of the Superintendent of the Coast Survey, Washington, USA, 1851.

U.S. Coast Survey: Report of the Superintendent of the Coast Survey, Washington, USA, 1855.

U.S. Coast Survey: Report of the Superintendent of the Coast Survey, Washington, USA, 1860. 